\title{
Maritime defence and the South African Navy to the cancellation of the Simon's Town agreement
}

\section{T.D. Potgieter}

\section{Summary}

For centuries, the maritime defence of South Africa was a colonial responsibility. First performed by the Dutch, the British took over the task after they wrestled the Cape of Good Hope from the Dutch. The Cape was of supreme strategic value to Britain as the link with India and a great part of her empire. Therefore for more than a century and a half (from 1806 to the abrogation of the Simon's Town Agreement) the Royal Navy had a constant presence in South African territorial waters. Furthermore when the first flickers of an indigenous maritime defence organisation appeared in South Africa it was British in character. The South African Division of the part-time Royal Naval Voluntary Reserve (RNVR) came into being long before the country had a navy. The origin of the South African Navy dates back to 1922, when, the South African Naval Service was created with the arrival of three small ships from Britain. Unfortunately, the budget cuts during the Depression meant that these ships and their crews were paid off (in 1933-4) and only a skeleton staff remained. This was still the position at the outbreak of the Second World War in 1939.

The Union of South Africa's declaration of war against Germany on 6 September 1939, meant that the country's utterly neglected Navy had to suddenly prepare for war. Ships had to be found, and as purpose-build warships were out of the question, ships from the country's fishing fleet and trade had to suffice. A small ocean-going navy was created for the defence of the Union's ports and coastline. Following an urgent request from the British Admiralty in November 1940, South Africa sent four anti-submarine vessels to join the Royal Navy in the Mediterranean. As the war progressed, more ships of the South African Naval Forces arrived in the Mediterranean. They were used for a variety of tasks, ranging from minesweeping to salvage work. South African ships and crews earned themselves quite a reputation, participating in most phases of the Mediterranean sea war, including operations along the North African coast, the invasions of Sicily and Southern France as well as subsequent operations in Greek waters. But losses also occurred, and in total four South African naval vessels were lost in the Mediterranean. 
After the war South Africa and Britain still shared the defence responsibility of the Cape Sea Route. South Africa also received warships plus equipment from the British. As part of the Simon's Town Agreement, signed in 1955, the South African Navy bought four frigates and other defence equipment from Britain. Despite the regular contact between the SA Navy and the Royal Navy, relations between the states worsened. South Africa bought submarines from France and when members of SA Navy visited the United Kingdom during 1971 to investigate the acquisition of new frigates or corvettes, it was clear that on the basis of politics, South Africa would not be able to buy new warships from Britain. Portugal was approached instead. On 16 June 1975 the two countries cancelled the Simon's Town Agreement, thereby ending more than 150 years of British naval presence in South Africa. In terms of maritime defence and the acquisition of defence equipment the link with Britain were now broken.

\section{Introduction and background}

The sea has always played an important part in the history of South African. It is via the sea and the sea-routes of communication that southern Africa and its inhabitants first came into contact with the inhabitants of Western Europe and other parts of the world. It is through this route that colonial conquest; settlers, new ideas and diverse cultural and economic influences entered South Africa. But despite its ideal location "on the crossroads of the world" South Africa is not a maritime nation. Furthermore, a local emphasis on the nature of maritime power and maritime defence requirements is lacking. This state of affairs could once again be ascribed to the influence of the sea on South African history. Because of South Africa's easy access to the world the sea brought new ideas, stimulated development and economic growth. This led to the conquest of a continuously greater part of South Africa; industrialisation followed, South African society experienced numerous conflicts and underwent transformation. The South African existence thus became embroiled with local political, economic and societal issues, rather than issues of maritime power. On the other hand, because of colonial involvement South Africans were never concerned about maritime defence.

British naval involvement in South Africa goes back to the British occupations of the Cape. For more than a century and a half (from 1806 to the abrogation of the Simon's Town Agreement in 1975) the British Royal Navy had a constant presence in South African territorial waters. During the twentieth century, after a small indigenous Navy came into being in South Africa it did not accept all the responsibility for maritime defence. The Royal Navy was around to first see to British imperial interests and then to assist the new fledging navy with the process of finding its feet. As the South African naval establishment developed, it took over the Simon's Town naval base, under the Simon's Town agreement it accepted responsibility for some of the tasks the Royal Navy previously performed and it became the overseer of the Cape sea-route. The political changes in South Africa however effected its naval establishment and led to the British link being severed. Maritime defence now became a solely South African responsibility - the South African Navy had to find its own way forward. 
This paper is based on archival documentation in the Cape Archives, the Military Archive Depot of the South African National Defence Force, the Armscor Archives and the South African Naval Museum. Most of the published sources available only address the history of the British Royal Navy, imperial defence requirements or the history of the South African Navy. While some of these sources are very accurate, many were compiled without proper archival research, resulting in certain errors. This paper finally is an endeavour to illustrate the development regarding South African maritime defence. It shows how the British assisted in the process, ending with the dilemma the severance of links with Britain caused.

\section{The maritime defence heritage: colonial style}

In a time when voyages were long and dangerous and the sea often beset with enemies it was important to have stations along the route, sometimes for trade, but primarily for defence and war. ${ }^{1}$ The Portuguese seafarers, already finding their way to the East around the southern tip of Africa before the end of the fifteenth century, were not interested in the colonisation of southern Africa, since they acquired good facilities on the east coast of Africa. For them, southern Africa was just the tip of a great continent they had to round on their way to the East and of no specific strategic importance.

\section{The Dutch Period}

During the seventeenth century, after the Dutch and the English also found their way to the East, they needed to refresh and rest their ships and crews along the way. The Dutch East India Company (VOC) hence decided in 1650 to establish a refreshment post in Table Bay, at the Cape of Good Hope (establishing it in 1652). Initially the little establishment around the picturesque Cape of Good Hope was of no particular economic or strategic importance. But is main value was as a refreshment station. Many ships just made it to the Cape, with their crews often too exhausted to even anchor their vessels properly. From the beginning the Dutch thought of protecting their settlement and immediately after their arrival they build a fort and commenced with the construction of a castle. Later, a whole variety of additional fortifications followed.

During the eighteenth century, as the trade with the East and competition between rival states and trading companies grew, it became essential to establishment safe sea-lanes of communication to the East. British interest in India grew and later, after the loss of her American colonies, Britain placed more emphasis on building an empire in competition with the French in the East. Being astride the sea-route and an important port of call halfway between Europe and the East, possession of the Cape was important. This impacted on the defence of the Cape. The Cape had to be defended not because of its inherent economic value or its importance as a colony, but because of its strategic location - the master of the Cape could control the route to the East. Hence a substantial system of fortifications 
was erected around the Cape Peninsular. ${ }^{2}$ Furthermore, specifically in time of war a big garrison was maintained at the Cape and during the late eighteenth century Dutch naval vessels were regularly on station at the Cape.

Even before the Cape was finally wrestled from the Dutch squabbling over it amongst the then 'great' powers of the world began. In 1781, during the American War of Independence Britain sent a squadron (two ships of the line, three ships of fifty guns and transports) under the command of Commodore Johnstone to seize the Cape. The French knew about the plan and sent a force under Admiral Suffren (five ships of the line and transports) to protect the Cape against a British expedition. While the British were at anchor at the Cape Verde Islands Suffren arrived and launched a surprise attacked on the British, throwing them off balance. Suffren then made straight for the Cape, arriving there before the British. When Johnstone arrived in Cape waters on 21 June he learned that Suffren had landed French troops in the Cape and that his ships were anchored in Simon's Bay. Because of the French troop reinforcements and French naval superiority in Cape waters, Johnstone decided not to attack the Cape. On his way back he nevertheless sailed into Saldanha Bay and captured five Dutch VOC ships at anchor in the bay. ${ }^{3}$ By the late eighteenth century it was clear that the process of 'big power' rivalry for control of the Cape of Good Hope because of its strategic location, has began.

\section{The British Occupations of the Cape}

During the French Revolutionary War it was above all in India that the British Empire expanded. India, the so-called jewel in the crown, was essential for British prosperity, but the long sea-route that channelled this wealth was vulnerable. When the Netherlands became a French ally in 1795, France, from a British point of view, threatened the security of the Cape sea-route. The sea-route caused much anxiety amongst the British and already in 1793 the directors of the British East India Company urged the British government to guarantee the Cape by British naval protection. After the events in Europe, Sir Francis Baring (Chairman of the Company) begged Henry Dundas (Secretary of State for War) to "secure" the Cape, stating that is was of value as a "place of refreshment for our ships ... and we should be much distraught for a substitute ... secondly, whoever is master of the Cape will be able to protect or annoy our ships." 4 For Baring the Cape "commanded the passage to and from India as effectively as Gibraltar does the Mediterranean." 5

Reports in the Cape Archives (hereafter referred to as CA) on the Cape Fortifications and the state of the Cape defences is very telling. See specifically CA. C714: Bijlagen: Guilquin and Thibault - Rhenius, 27 February 1792, pp 69-75 as well as CA. C704. Bijlagen. Generale Staat van Ammunitie en Goederen van Oorlog, November 1792, pp 105-106.

Mahan, pp 421-7. February 1793 to December 1796(London, 1897), pp 19-23. 
Soon after, Britain dispatched a task force to the Cape with Admiral Elphinstone Viscount Keith, as commander. The British utilised the political differences at the Cape and the general discontent with VOC control to the fullest in their assault on the Cape. Eventually the Cape capitulated on 16 September 1795 after a campaign of about three months that saw very little military action, but would be remembered for its political and psychological dimensions. ${ }^{6}$

After their take-over the British wanted to establish their authority firmly and the Cape was placed under the military rule of Major-General Craig. ${ }^{7}$ Since many burghers in the interior supported the Batavian Republic they defied British authority and hoped for a Dutch or a Dutch-French attempt on the Cape. The British therefore stationed additional troops and warships at the Cape.

Early in August 1796 a Dutch squadron under the command of Admiral Lucas (with two ships of the line, three large frigates and four smaller ships), anchored in Saldanha Bay. Lucas wrongly believed that French help would be forthcoming for an attempt on the Cape and decided to wait in Saldanha. With the arrival of the Dutch ships hope flared up amongst the population for a Dutch takeover. General Craig immediately marched to Saldanha with a force of 2500 soldiers while Admiral Elphinstone set sail for Saldanha with an overwhelming force of 13 ships of the line. ${ }^{8}$ On arriving at Saldanha Elphinstone dispatched an officer to Lucas requesting the Dutch to surrender and "... spare an effusion of blood ... otherwise it will be my duty ... of making serious attack ... the issue of which is not difficult to guess". ${ }^{\text {. }}$ Lucas realised that he was no match for the British and surrendered to Elphingstone on 17 August. $^{10}$ The burghers on the frontier only gave in when the prospect of reoccupation of the Colony by the Dutch receded with the capture of Admiral Lucas's fleet. During the rest of the First British Occupation (to 1803) the Royal Navy was omnipresent at the Cape, ensuring its security.

After Admiral Nelson's victory at Trafalgar, naval opposition to Britain basically ceased to exist. Since Britain now no longer had to maintain lengthy resource intensive blockades of its continental enemies, ships and escorts were more readily available to protect the many trade convoys and merchant ships - Britain's true life blood. The Royal Navy could be employed to hit a blow where it was desired, either in support of Britain's allies or, as it usually happened, for the

See T.D. Potgieter, The First British Occupation of the Cape (Cape Town, 1995).

7. H.J. van Aswegen, History of South Africa to 1854 (Pretoria, 1990), p 156.

8 C.J. de Villiers, Die Britse Vloot aan die Kaap, 1795-1803, (Unpublished MA, UCT, 1967), pp 86-88.

9. P Erskine, "Admiral Elphinstone's Naval Task Force 1795-96" in Antiques in South Africa, nr.12 1983, p 88.

10. De Villiers, pp 92-93. 
maintenance and advancement of Britain's own strategic aims. Britain exploited her command at sea, often by capturing the overseas colonies of France and her allies. "I

With the overseas trade of Britain undergoing enormous growth it also provided a vast array of potential prizes to privateers across the globe operating from bases such as Martinique, Guadelope and Mauritius. British losses to privateers were substantial and the Admiralty was therefore eager to secure bases across the world, to gain advantageous positions on the major trade routes and to eliminate potential bases from which commerce raiders might operate. One of the specific concerns were the vital trade route to the East and since the Cape was handed back to the Batavian Republic in 1803, British apprehension became great. The route to the East had to be protected and trading vessels had to be safeguarded. These strategic motivations led to the Second British Occupation of the Cape in 1806 - and once again (this time permanently) Britain secured the Cape.

As always, in the colonial struggles between Britain and her European rivals, sea power ultimately decided the outcome. ${ }^{12}$ Britain's ability to contain her enemies' fleets within European waters and to punish them severely whenever they emerged from port, turned the scale and determined the fate of the Cape. During the Napoleonic Wars the Royal Navy learnt that the raison d'être for the existence of a navy is not only linked to trade protection, blockading the enemy, stopping invasion attempts, destroying the enemy's navy and ruining the enemy's trade, but also to project decisive military power across the seas. As Britain succeeded in all of the above, by the end of the Napoleonic Wars, she became the unchallenged mistress of the sea.

\section{British imperial interests and maritime defence during the Pax Britannica}

The fact that Britain possessed naval mastery in the nineteenth century led to her commerce expanding, which in turn made the acquisition of strategic points necessary and easy, while holding these ports on the other hand reinforced British supremacy and created further opportunities for economic growth. Britain controlled a wide variety of the choicest strategic ports on the sea-lanes of the world and as Admiral Fisher would later suggest, they were "the 'keys' which locked up the globe." In itself the Cape was not of great importance to Britain, but it added to the strategic defence of the Empire and control of the Cape kept vital maritime links clear. It was regarded as the true centre of the British Empire, as it was clear of Suez complications, and nearly equally distant from Australia, China, India, Gibraltar, the West Indies and the Falklands. In fact according to Kennedy, Cape Town was "perhaps the most important strategic position in the world in the age of sea power."

E.B. Potter \& C.W. Nimitz, Sea Power (London, 1960), pp 168-9.

Ibid., pp 129-131. 
Despite the strategic importance of Cape, it must be emphasised that colonial planners regarded India (not Africa) as central to British commercial interest and status as an imperial power. Hence save sea-lanes of communication and the creation of sufficient save port facilities on the route to India, both through the Suez Canal and round the Cape, was essential. This meant that southern Africa's prime importance (as that of Egypt) was in its strategic location. In southern Africa it was difficult for Britain to maintain its dominance because of the political and economic fragmentation of the region. The existence of Boer republics, independent black kingdoms and British Colonies with ill-defined boundaries led to endemic conflicts and a perception amongst imperial planners that a comprehensive new political structure should be erected in South Africa. The constant conflict in South Africa was a major obstacle and posed a security risk in the path of a proposed "confederation" in southern Africa, leading to such wars as the Anglo-Zulu War of 1879 in an effort to "enable the sub-continent to fulfil its imperial strategic role."14

During the Anglo-Boer War British sea communications with the rest of her empire were essential. After the outbreak of the war Britain transported an immense body of soldiers with equipment and supplies to South Africa, over a distance of at least 6000 miles (Southampton to Cape Town). Mahan calculated that between 20 October 1899 and 31 March 1900 alone, the "truly gigantic figure" of approximately 166277 men sailed for South Africa from Britain (not counting troops that arrived from India). The Royal Navy essentially oversaw this meticulous process at the different ports, a truly remarkable feat. ${ }^{15}$ For the rest of the war the movement of troops and supplies into South Africa from across the British Empire continued. The enormous resources of the empire and the capacity to mobilise, utilise and move it, led to substantial forces being deployed in South Africa from Britain, Australia, Canada and New Zealand. Altogether about 450000 imperial and colonial troops served in South Africa during the Anglo-Boer War.

The effect of British naval mastery was also illustrated by the fact that the Royal Navy had the capacity to stop other European nations, who sympathised with the Boers from putting their sympathy into meaningful support. In fact the historian G.D. Scholtz is emphatic that historians neglect British sea power as a crucial determinant in the history of South Africa. British sea power prohibited other powers from getting involved in the affairs of Southern Africa. ${ }^{16}$ A number of examples testify to this. General Buller wanted the Royal Navy to impose a complete naval embargo on the Boer Republics, by blockading the Portuguese port at Delagoa Bay. Although Milner backed him, the British Cabinet only agreed to an arms embargo. As a result the Royal Navy prudently kept an eye on shipping to Delagoa Bay, even forcing into port and searching three German ships; the Bundesrath (in December 1899) and the Herzog and General (in January 1900) on

J. Laband \& P Thompson, The Illustrated Guide to the Anglo-Zulu War (Pietermaritzburg, 2000), p 3. 
suspicion that they carried arms and ammunition to the Republics. They did not, but the incident however created a storm of protest in Germany. ${ }^{17}$ Furthermore, after the outbreak of the war Britain concluded a secret treaty with the Portuguese, vowing to defend Portuguese colonial possessions if the Portuguese promised to stop the movement of arms and ammunition to the ZAR. British officials thus co-operated closely with Portuguese officials in Lourenco Marques. $^{18}$

For the remainder of the war the Royal Navy kept a close watch on the South African coast and British warships were ever present. This even led to the odd scrap with the Boers like the incident on 10 October 1901 when a Boer patrol exchanged fire with the HMS Partridge in Saldanha Bay. ${ }^{19}$

The Anglo Boer War is a good example of the role maritime power and naval forces can play in the projection of force. In this case the fact that there was no threat along the long sea lines of communication, also made it much easier for Britain. British maritime capacity was therefore a critical variable that ensured success in the war. As military power in analysis consists principally of two factors, force and position, the British had both. The proper position ing of their force in the theatre of operations was made possible by maritime and naval power and facilitated by the improvements in technology and communication.

\section{The origins of the South African navy and the First World War}

In times of crisis navies usually rely on part-time naval reserves for manpower. South Africa was no exception, but the difference is, that naval volunteer units existed long before South Africa had its own navy. This implied that when the first flickers of an indigenous maritime defence organisation appeared, it was British in character. The first successful reserve was the Natal Naval Volunteers (NNV) created in Durban on 30 April 1885 while in Cape Town a naval volunteer unit was created on 1 February 1905, under the name Cape Colonial Division Royal Naval Volunteer Reserve. ${ }^{20}$ Besides this the colonies also contributed more directly to maritime defence with the colonial governments of the Cape and Natal making annual contributions to the Royal Navy from 1898 and 1903 respectively, with Natal also providing supplies of coal. In the Cape, the colonial government passed the Simon's Town Defence Act in 1898, authorising the development of a base for the Royal Navy. The new dockyard (completed in 1910) with a 228 metre graving dock and a protected tidal basin, became the base for the Royal Navy's Cape of Good

Pakenham, p 253.

F. Pretorius, Life on Commando during the Anglo-Boer War (Cape Town, 1999), p 83. 
Hope Station. The Royal Navy showed its appreciation to the colonies by naming two armoured cruisers HMS Good Hope and HMS Natal. ${ }^{21}$

With the creation of the Union Defence Force (UDF) in 1912 the two naval volunteer units were amalgamated. The new division, called the South African Division of the Royal Naval Volunteer Reserve (RNVR(SA)), officially came into being on 1 July 1913 in accordance with the South African Defence Act of $1912 .^{22}$ Although this division would be financially maintained by the Union Government and constitutionally formed part of the UDF, it had to be placed at the disposal of the British Admiralty in time of war and the Royal Navy assumed responsibility for its peacetime organisation, training, administration and discipline.

Before the outbreak of the First World War, the then Minister of Defence, General J.C. Smuts, entertained a scheme for the creation of an indigenous South African Navy similar to those of Australia and Canada. However the First World War broke out before the plan could be executed and by 1914 the maritime protection of South Africa and the Cape sea-route was still the task of the Royal Navy. Immediately after the outbreak of the war the RNVR(SA) mobilised its members for service onboard Royal Navy vessels and at shore establishments. ${ }^{23}$ Many of them participated in the South West Africa Campaign, in the East African Campaign, served in the Mediterranean and in British waters and also manned the harbour defences of Durban throughout the war. The British Admiralty also took up a number of South African registered ships for service during the war and though many South Africans served on such vessels, they remained Royal Navy units.

When the war ended members of the RNVR(SA) were demobilised and South African ships requisitioned by the Admiralty was either returned to its owners or sold. With no navy of warships of her own, South Africa was thus still dependent on Britain for maritime defence.

The situation though, would soon change. At the Imperial Conference held in London in 1921, Smuts agreed that South Africa should discontinue its annual contribution to the Royal Navy ( $£ 85000$ at that stage) in order to establish a permanent seagoing force of its own. It was decided that the new naval force would consists of sections for general duties, minesweeping and hydrography, that the RNVR(SA) would be expanded and South Africa would assist with the further development of the naval base at Simon's Town.

Consequently the Admiralty made three small ships available to South Africa namely the HMS Crozier (a Hunt class minesweeper converted into a survey ship, renamed the HMSAS Protea), and two minesweeping trawlers, HMS Foyle 
(renamed HMSAS Sonneblom) and HMS Eden (renamed HMSAS Immortelle). ${ }^{24}$ These ships arrived in False Bay on 11 January 1922 and were re-commissioned as South African ships on 1 April 1922. The crews belonged to a new arm of the UDF, the South African Naval Service (SANS), consisting of 16 officers and 117 ratings. SANS became a permanent unit of the Union Defence Force on 1 February 1923. Its first "chief" was Commander N.H. Rankin, a retired Royal Naval Captain. His official designation, Commander South African Division was later changed to Officer Commanding SANS. In order to provide the SANS with a nominal mothership on whose books all SANS personnel could be placed, the depot ship HMS Africander was transferred to the SANS on 15 June 1923, becoming the HMSAS Africander. In reality though the administrative headquarters of the SANS was in a number of buildings on the quay at Simon's Town. ${ }^{25}$

The small SANS was not meant to last. Ironically it was plagued by the type of problems the SA Navy have become so accustomed to during the first seventy-eight years of its existence; namely manpower and budgetary constraints. Finding suitable officers to man the ships remained a problem during its first decade and plans to acquire an additional warship in 1926 was shelved because of a lack of funding. Then, as a result of the Depression of the thirties, defence expenditure was severely curtailed, with SANS suffering badly: The post of Officer Commanding was discontinued on 4 November 1932 with command and administration returning to the Royal Naval Commander-in-Chief Africa Station. After negotiations the HMSAS Protea was paid off on 30 April 1933 and the complement of the SANS reduced. Although the two minesweepers stayed in service for another year, they were eventually taken out of service on 31 March 1934 and returned to the Royal Navy. With only a skeleton staff of four officers and twelve ratings remaining, the SANS disappeared as a seagoing force. Its tasks was to continue with hydrographic survey work (in conjunction with the Department of Sea Fisheries) and to administer and train the flourishing RNVR(SA). ${ }^{26}$

\section{South African naval participation in the Second World War}

When South Africa entered the Second World War on 6 September 1939 the SANS was virtually non-existent, it had no ships and comprised of only two officers, both lieutenant commanders, and three ratings. However before the outbreak of the war, it did consider acquiring ships in the case of an emergency and during the late 1930's the SANS conducted numerous surveys to established which vessels (in trade, fishing and whaling) could be used for anti-submarine and minesweeping duties. ${ }^{27}$ They considered trawlers and whalers to be the most

Cape Times, 13 January 1922.

J.C. Goosen, Ons Vloot (Cape Town, 1973), pp 13-17.

26.

T.D. Potgieter, Die Geskiedenis van Projek Taurus en die Missielbootprojekte (Unpublished MA, RAU, 1992), pp 14-16.

MAD. South African Naval Forces SANF. Box 10. Reports on vessels registered at South African Ports.
} 
suitable vessels available and subsequently compiled a comprehensive list early in 1939. By comparison the SA Division of the Royal Naval Volunteer Reserve, RNVR(SA), consisting of part-time volunteers, was a thriving organisation and was still under the control of the British Admiral in Simon's Town.

After the outbreak of the war the structure and nature of South African maritime defence establishment changed drastically. General J.C. Smuts (South African Prime Minister and Minister of Defence) approached Rear-Admiral G.W. Hallifax, a retired Royal Naval officer then living in South Africa, offering him the post as Deputy Director of Coast Defence and Officer Commanding SANS. Hallifax accepted and during October he settled into an office in the Castle at Cape Town with a small staff to create the new service. ${ }^{28}$ The recruitment of personnel for seaward defence, the protection of harbours, and overseas service commenced. As no purpose-built warships could be found, some of the ships identified earlier were requisitioned and converted for maritime defence purposes. ${ }^{29}$

On 25 October 1939 the Union Government informed the British High Commissioner that South African forces must accept full responsibility for "certain services in connection with the defence of Union ports and coast line" and that a new force, the South African Seaward Defence Force (SDF) will be formed. By the end of October Halifax already referred to his appointment as the Director Seaward Defence Force and on 15 January 1940 the SDF was formally constituted. At this stage it had a total strength of 428 (47 officers), 17 vessels in service and a few offshore establishments. ${ }^{30}$ Unfortunately, just as his efforts to create a viable indigenous South African Naval Force was showing results, Halifax died in an aeroplane crash on 28 March. Capt J. Dalgleish succeeded him as Director SDF.

At this stage the SDF and the RNVR(SA) was still separate entities. Since the Union Government had for some time been in favour of amalgamating them, they discussed the matter with the British Admiralty. The amalgamation was agreed upon and from 1 August 1942 the new amalgamated force, with Dalgleish as its Director, was known as the South African Naval Forces (SANF). Its responsibility was the protection and defence of the Unions' ports and coastline, as well as minesweeping duties and anti-submarine patrols in the approaches to South African ports.

Regarding the process of converting and fitting out of vessels for the South African naval establishment work progressed well. The first three minesweepers (converted trawlers), manned by members of the RNVR (SA), were

L.C.F. Turner, H.R. Gordon-Cumming and J.E. Betzler, War in the Southern Oceans, 1939-45 (Cape Town, 1961), p 19.

29. MAD. Secretary for Defence, Group 2. Vol 9. Box 3204-3207. 
readied for service in September 1939. By 15 January 1940, when the SDF were formally constituted it comprised of 17 requisitioned ships (15 minesweepers and two examination vessels). The first minesweepers were converted trawlers armed with a 12-pounder, a Lewis gun or two and a pair of depth charges, but they carried no submarine detectors (asdics). Sufficient equipment for anti-submarine vessels was initially a problem and asdics sets were in short supply. ${ }^{32}$ After the Royal Navy supplied the Union with four sets and instructors in January 1940, the first two trawlers (Mooivlei and Blomvlei) were converted into anti-submarine vessels, commencing with their duties during April. Furthermore additional training facilities were immediately established since anti-submarine training was regarded as of specific importance. ${ }^{33}$ Initially the workshops of the SAR \& H (South African Railways and Harbours) performed the conversion work on vessels, but in February 1940 they complained to the Secretary of Defence that they could no longer cope with all the conversions. Authority was subsequently granted to place some of the work with a number of private firms under the supervision of the Admiralty.

These then were the important local developments regarding the creation of a wartime navy for South Africa. During the war SANF personnel and vessels performed their duties in South African waters as well as in other parts of the world. A number of SANF vessels participated in most phases of the war in the Mediterranean ${ }^{34}$ and just under 3000 South African officers and ratings served in the Royal Navy, literally across the globe, as personnel seconded from the RNVR(SA).

From May 1940 (for over eighteen months) the SDF Mine Clearance Flotilla was engaged in clearing the mines laid by the German raider Atlantis near Cape Agulhas and later conducted mine clearance operations off Cape Columbine, Danger Point and in the approaches to Table Bay. Furthermore they co-operated with Royal Navy units in intercepting a Vichy French convoy off Port Elizabeth in November 1941.

Throughout the war anti-submarine operations and escort duties around the South African coast consumed much of the time and energy of the SDF and SANF. Following the escalation of the war in North Africa, the Cape sea-route became vital to the allied war effort. With South African ports congested and enemy submarine activities on the rise, extensive anti-submarine defences were established at Saldanha Bay. In the meantime submarine attacks became common with thirteen ships being sunk in four days in October 1942. SANF ships conducted regular antisubmarine patrols in the approaches to South African harbours and regular anti-

MAD. Seaward Defence. SD. Box 3 : A/S vessels and Equipment. Office of Senior Naval Officer Simon's Town to Secretary for Defence, 29 December 1939. Defence to Secretary of Defence, 6 February 1940. 
submarine operations led to the rescue of 400 survivors from torpedoed ships. In all submarines sank 133 merchant ships within 1000 nautical miles of the South African coast, whilst only two U-boats were destroyed. ${ }^{36}$ Submarine activities in South African waters were only curtailed by the introduction of a group convoy system and improved air reconnaissance.

The involvement of vessels from the small South African naval establishment in the Mediterranean was the result of an urgent request from the British Admiralty to the South African Government on 20 November 1940. The Commander in Chief ( $\mathrm{C}$-in-C) of the Mediterranean Fleet, Admiral A.B. Cunningham urgently needed more anti-submarine patrol vessels and indicated that the converted vessels in use in South Africa would suffice. Rear-Admiral Hallifax (Director SDF), suggested that newer and larger vessels, superior in speed and seaworthiness (the HMSAS Southern Floe, Southern Isles, Southern Maid, and Southern Sea) be sent. ${ }^{37}$ The Admiralty was notified on 22 November and Cunningham promptly requested that they sail for Alexandria as soon as possible. ${ }^{38}$

Soon (15 December 1940) the small flotilla of the four converted whalers, called the 22nd South African Anti-Submarine Group under the command of Lieutenant-Commander A.F. Trew ${ }^{39}$ left Durban and sailed for the Mediterranean. ${ }^{40}$ They arrived in Alexandria on 11 January 1941 where the ships were placed under the command of Admiral Cunningham. He regarded their arrival as "most welcome $^{n 41}$ and after he was informed that the officers and crews were mostly in their twenties, he responded "Good - that's what you want in small ships. Young men, hard work, hard fighting!" ${ }^{42}$ The South Africans soon realised that this was indeed the case as they were immediately put to work on convoy and patrol duties on the exposed route between Alexandria and Tobruk. Exposed to constant air

For a thorough discussion see the unpublished manuscript at the MAD by H.R. Gordon-Cumming, History of the South African Naval Forces, 1939-45, as well as Goosen and Du Toit.

MAD. SD. Box 3. SD3/13 and 16 and MAD. SD. Box 3. SD3/15. Signal message Operations Centre Cape Town to Admiralty, 22 November 1940. See also MAD. South African Naval Forces SANF. Box 10. Inspection of vessels for service in Emergency, 22 December 1936.

MAD. SD. Box 3. SD3/15. Signal SNO to Dechief. 25 November 1940.

Lieutenant Commander A.F. Trew was appointed Senior Officer South African Ships in the Mediterranean. The material on Trew in the SA Naval Museum, Simonstown (hereafter referred to as SANM) is quite good. See SANM File: Lieut Cdr A.F. Trew, DSC. Biographical details. See also MAD. Personnel Files. P1/4869 A.F. Trew. History Sheet Lieut Cdr A.F. Trew.

MAD. SD. Box 3. SD3/15. Releasing of Vessels for Service with RN and Box 4. SD3/15. Batch II, Signal message C-in-C Med, 22 January 1941.

SANM. File : Lieut Cdr A.F. Trew, DSC. Trew to Halifax, 25 February 1941. 
attacks they tackled their task with vigour and zeal, receiving constant praise. Sadly however the HMSAS Southern Floe became the first South African naval casualty of the war as she struck a mine and sank off Tobruk on 11 February $1941 .{ }^{43}$

The HMSAS Protea was sent to replace the Southern Floe, where after the number of South African ships serving in the Mediterranean increased. At its peak thirteen South African vessels (four anti-submarine vessels, eight minesweepers and the legendary salvage vessel Gamtoos) were serving in the Mediterranean. Besides their bold exploits on the Tobruk run these vessels participated in most phases of the Mediterranean sea war, including operations along the North African coast, the invasions of Sicily and southern France as well as subsequent operations in Greek waters.

More losses however occurred, and the minesweepers HMS Parktown, Bever and Treen were also lost in the Mediterranean war. To her distinction the Parktown was the last allied ship to leave Tobruk before the town surrendered. She took a disabled tug in tow as she left Tobruk, which slowed her down considerably and as she could not make her escape in time, she was sank by E-boats (or MASboats) off Tobruk. ${ }^{44}$

A legend of the Second World War is the salvage vessel HMSAS Gamtoos. Despite her unglamourous appearance and humble origins (a coal burning coastal steamer) the HMSAS Gamtoos performed the strategic important tasks of clearing blocked and booby-trapped harbours. In North Africa her clearance of the Tripoli harbour entrance was of the utmost importance to the allied forces as it enabled urgent supplies to reach the army when they needed it most. ${ }^{45}$ She completed a considerable amount of salvage work in numerous harbours and was also the first allied ship to enter Marseilles. For her remarkable achievements she won the praise of many.

These "little ships", in which the South Africans served in the Mediterranean were small and uncomfortable and were built for duties vastly removed from those which they performed. But these ships and their crews served with distinction, throughout the war. ${ }^{46}$

MAD. SD, Box 4. SD3/15/1. Casualties 22 A/S Flotilla. Signal C-in-C Med to SNO Simon's Town, 12 February 1941 and Signal DIRSEA to DEWAREC, 15 February 1941.

MAD. Naval Ships Logs. Box 216. Reports of proceedings. HMSAS Parktown, lost by enemy action 21 June 1942 and Loss of the Parktown dated 24 June 1942.

MAD. Naval Ships Logs, Box 50. HMSAS Gamtoos, March 1943 and SD Box 5. SD3/15/16. SANF Monthly reports Mediterranean Station. Report 18 September-14 October 1943.

T.D. Potgieter, "South African Naval Vessels in the Mediterranean during the Second World War" in Jounal for Contemporary History, June 1998. 
A notable event in South Africa's naval history occurred in the last year of the war when South Africa received its first purpose-build warships. This occurred with the British offer in May 1944 to make three frigates permanently available to the SANF, for the exchange of 3600 recruits for service in the Royal Navy, spread over the following twelve months. From a manpower point of view, this would not have been possible. South Africa had to keep the Sixth Armoured Division (fighting in Italy) at full strength and did not even manage to keep up the full monthly quota of 40 seconded SANF personnel. Was it not that a number of minesweepers were to be taken out of service three months later, it would have been difficult crew the frigates. The Acting Minister of Defence (Mr F.C. Sturrock) then suggested that the frigates be accepted but in order to make up for not providing the manpower to the Admiralty, the frigates would be available for service with the Royal Navy. This was agreed upon and on 22 July the Union Government formally accepted the offer. $^{47}$ Afterwards it became known that these ships were three new Loch class frigates, then under construction and considerably larger than the existing River class frigates. The first of these ships (the HMSAS Good Hope) was commissioned on 9 November 1944, followed by the Natal on 1 March 1945. As both ships entered service before the end of they war, they served in the North Atlantic during the final days of the war. The Natal, under the command of Lieutenant-Commander D.A. Hall, even had the distinction of sinking a U-boat whilst still on trails. The commissioning of the HMSAS Transvaal took place too late for the ship to serve during the war, and she arrived in Cape Town in July $1945 .^{48}$

In analysing South Africa's maritime defence role during the Second World War it is noteworthy to add that it did not only include providing naval units and personnel for the allied war effort. An important contribution the Union of South Africa made, was the supply of war materials as well as war production and ship repair and maintenance. Before the outbreak of the war very little ship repair was done in South Africa. During the war the demand on South African facilities increased because of the growing traffic around the Cape and the fact that the British Admiralty and many ship owners preferred to have ship repair and maintenance done away from the reach of German bombers. ${ }^{49}$

Although the harbours of the Union of South Africa did not have developed ship repair facilities at the outbreak of the war, a number of well equipped workshops existed that were improved upon. Specifically during the first years of the war (with heavy traffic to and from the East around South Africa) the Union's

H.R. Gordon-Cumming, "The Acquisition of Three Frigates by the SA Naval Forces" in Militaria, 22/1 1992, p 43.

See Du Toit, pp 158-61 and Goosen, pp 47-50.

E. Pienaar, Enkele Ekonomiese Aspekte van die Voorsiening van Krygsvoorrade aan die Unieverdedigingsmag met spesifieke verwysing na die Produksie van Krygsvoorrade in die Unie van Suid-Afrika gedurende Wêreldoorlog II, 1939-45 (Unpublished D Com, UP, 1964), pp 49-50. 
harbours became essential ports for repair and maintenance in the allied supply lines. These harbours therefore had great strategic value for the allies.

Many allied warships, damaged in the war at sea just managed to reach South African ports where they were repaired and re-deployed operationally. Because of the very high premium placed on ship repair at South African ports, the harbour administration and repair facilities (functioning under the Director-General War Supplies, later Director-General Supplies) received priority from the government in terms of manpower, resources and machinery. At its peak, the Union's facilities had the capacity to repair and equip up to 250 ships a month. ${ }^{50}$ In this sphere South Africa's contribution was essential in supporting and ensuring the flow of maritime traffic.

Clearly, the maintenance of sea-lanes of communication around the southern tip of Africa was of strategic importance to the allied war effort during the Second World War. Specifically between June 1940 and May 1943, with the Mediterranean closed to Allied shipping, the Cape sea-route once again lived up to its name and assumed its historic primacy in strategy. For the Allies the strategic position of the Union of South Africa was of great value. Because of its location, far from the theatres of war, the Union was save. The only South African front that saw action during the war was the sea front, with enemy submarines operating in the seas around South Africa. Without the Cape route, the Commonwealth could hardly have survived the war, without the Commonwealth, the Russians and Americans could hardly have won it. But the victory in North Africa changed all that, and after the Mediterranean was open again, the Cape route, although useful, was no longer vital.

\section{The post-war era: maritime defence becomes a South African responsibility}

In accordance with the international demobilisation that took place after the Second World War, the SANF received a number of cutbacks. However, since the Union government wanted to maintain a permanent seagoing fleet for the defence of South Africa, the SANF was reconstituted on 1 May 1946 as a permanent part of the Union Defence Force with 60 officers and 806 men. Only 17 of the altogether 89 wartime vessels were maintained namely the three Loch class frigates (HMSAS Transvaal, Good Hope and Natal), the minelayer HMSAS Spindrift (later SAS Skilpad), two boom defence vessels (HMSAS Barcross and Barbrake later SAS Somerset and Fleur) and eleven harbour defence motor launches. ${ }^{51}$

The next important acquisitions in terms of vessels were two ex $W \& V$ class destroyers (HMS Wessex and Whelp renamed the HMSAS Jan van Riebeeck and the SAS Simon van der Stel) in 1950 and 1953 respectively. In the meantime the 
SANF was renamed the South African Navy (SAN) on 1 January 1951 and the prefix to SA Naval vessels became SAS instead of HMSAS on 20 June 1952.

South Africa now formally had a navy that, because of its history and the strong links between South Africa and Britain, was strongly aligned with the Royal Navy. It was a small, but typical western navy and in terms of ships, equipment, training and nature the SA Navy was so typical Royal Navy that in jest it was often referred to as the 'Royal South African Navy.' In accordance with British strategy the SA Navy build up its strength as an anti-submarine and convoy force, operated ships designed for the imperial role of Britain and not for the maritime defence requirements of a small developing country. ${ }^{52}$ Sitting at the choke point of one of the busiest sea-routes in the world, together with the Royal Navy (operating from Simon's Town naval base) the SA Navy acted as custodian of the Cape Sea Route. Contact between the two navies was however very important, especially for the young, developing SA Navy.

\section{The Simon's Town Agreement}

Simon's Town has served as a VOC anchorage since 1671 and was home to the Royal Navy's South Atlantic Squadron since 1814. After 1910 it legally became part of the Union, but the Union guaranteed its use to the Royal Navy as the coastal defence of South Africa and the protection of the sea-route was in essence in British hands. In December 1921 the Union government took over the Admiralty property in Simon's Town and after the creation of the SANS in 1922 the Union undertook to maintain the base in order to ensure its utility in the maritime communications network of the British Empire. Legally the base would therefore form part of the Union while Britain was guaranteed its use. ${ }^{53}$

After the war the relations between Britain and South Africa initially continued on the same basis as before the war. But, it would change drastically during the next three decades because of political changes in South Africa as well as the effect of the Cold War. When the Nationalist Party came into power in 1948, the new government felt that South Africa had its own maritime defence requirements and should be more independent. They wanted to assume control over the Simon's Town naval base. What followed was a series of negotiations, also referred to as the Anglo-South African Correspondence or the Simon's Town Agreement.

In terms of Simon's Town Agreement the SA Navy took over the base in 1957. The treaty was favourable to British interests as it allowed, amongst other provisions, Britain and her allies to use the base and its facilities even in a war in which South Africa was not engaged. The Agreement made provision for a strategic zone in which the two navies would operate under the operational authority of the

Potgieter, Geskiedenis, pp 21-22.

A. du Plessis, "Die Maritiem Strategiese Betekenis van Simonstad-Vlootbasis" in Issup, November 1979, p 19. 
British Commander-in-Chief South Atlantic as well as for an area that would be the direct responsibility of the SA Navy.

For the SA Navy the most important outcome of the Agreement was the understanding that South Africa should acquire certain vessels and equipment necessary for coastal defence, from the UK. ${ }^{54}$ As a result a program for the requisitioning of ships were approved. The programme, stretching over a period of eight years (1955-63) provided for the purchase of six frigates, ten coastal minesweepers and four seaward defence boats. ${ }^{55}$ Subsequently South Africa purchased the SAS Vrystaat (formally the HMS Wrangler a converted W\&V class destroyer), as well as three type 12 anti-submarine frigates (the SAS President Kruger, Steyn and Pretorius). Acquiring the three type 12's is specifically noteworthy since they were the first major warships that were ordered and built for the SA Navy. Because of rising costs only four frigates were purchased and not the original six as planned, while five seaward defence boats and ten minesweepers were purchased. Yet, these ships were all from existing Royal Navy classes, designed according to Royal Navy specifications.

By the beginning of the sixties, due to the racial policies of the National Party Government and the events in South Africa (the resistance to Apartheid and the Sharpeville incident) ill will towards South Africa was generated abroad and the country increasingly became isolated from the international community. When South Africa became a republic and left the British Commonwealth in 1961, the decolonisation of Africa was in full swing. As numerous 'new states' called for sanctions against South Africa, from 1963 onwards the United Nations accepted a number of restrictive resolutions regarding the sale of weapon to South Africa. These developments placed the Simon's Town agreement in jeopardy.

With the election of a Labour Government in the UK in 1964, the sale of weapons to South Africa ceased, but the British government still honoured existing contracts and provided spares in terms of the Simon's Town agreement. In June 1967, due to cutbacks in British overseas defence commitments and her so-called withdrawal "east of Suez" the Royal Navy also decided to withdraw its frigates from the south Atlantic. HMS Lynx the last British frigate 'on station' at Simon's Town departed on 17 June 1967. ${ }^{56}$ The principle of the Simon's Town Agreement (granting the use of the naval base in times of peace and war to the Royal Navy) however, remained unchanged.

Despite the regular contact (training and joined exercises) between the SA Navy and the Royal Navy, relations between the two signatories of the Simon's Town Agreement worsened. After the new Labour Government came to power in

AA. RSA Verdragreeks no 2/1955: Ooreenkoms tussen Suid-Afrika en Verenigde Koninkryk betreffende Verdedigingsaangeleenthede, $\mathrm{p} 3$. Ibid, p 9. 
Britain in 1973 it immediately reintroduced an armaments boycott against South Africa. Both sides in any case doubted the merit and effectiveness of the Agreement. The South African Government was of the opinion that Britain did not show much for their unilateral achievement of keeping the naval base available to Britain while the British Government on the other hand saw the Agreement as a political liability with marginal military value. On 16 June 1975 the two countries cancelled the agreement.

The de jure cancellation of the Simon's Town agreement that officially ended more than 150 years of British naval presence in South Africa, was only the result of the de facto situation (worsening political relations between South Africa and Britain) that already existed for a number of years. The result was that South Africa could not approach Britain for warships and consequently important SA Navy vessel acquisition projects were launched in the late sixties and early seventies (before the cancellation of the Agreement) without British involvement.

\section{Exploring other avenues for vessel acquisition: submarines from France and corvettes from Portugal}

The SA Navy's links with the Royal Navy was so strong that, as a prominent former Chief of the SA Navy and Commandant-General of the South African Defence Force (SADF) stated it became a matter of course. ${ }^{57}$ However with the changing political climate, especially during the sixties, naval planners for the first time realised that they would have to consider an independent way forward, without the guidance of big brother Royal Navy. It dawned on them that South Africa and not Britain had to take total control of its $5000 \mathrm{~km}$ long coastline and its maritime defence. It was no longer possible to rely on Britain to assist with maritime defence, to provide aid with the training and education of officers and men. The SA Navy will be forced to investigate other avenues for purchasing warships and equipment. That was exactly the case when it became clear that the SA Navy needed new ships (submarines and frigates) to commence service by the early and middle seventies.

The first attempt to buy ships from another source was the SAN's submarine project. Submarines were regarded as important for the protection of South Africa's extensive maritime interest as they could both serve as a deterrent and a strike force. Because of the longstanding relationship with Britain the project team initially showed interest in the British Oberon class then being build for the Royal Navy. However the Labour Government (that came to power in 1964) wanted to institute an arms embargo on South Africa, with the result that France was approached to supply the SA Navy with three Daphne class submarines. The project was first announced in Parlement in May 1965 and after negotiations the contract was signed with Dubigeon-Normandie on 10 February 1967. The submarine project 
was a very well planned and executed project as delivery of the three submarines took place between 1970 and 1972, on target and within the budget. ${ }^{58}$

In the late sixties the SA Navy conducted a thorough investigation into the value of South Africa's maritime attributes and commenced with a planning process on the future of the navy. They concluded that because of its maritime resources, rich fishing potential, international trade and industrial capacity South Africa's maritime communications is of great importance to the Republic. South Africa's network of ports was considered to be the largest, best equipped and most efficient on the African continent. Consequently the imports and exports of South Africa and numerous of her neighbouring countries were conducted through these ports. But what was the SA Navy's role in securing these vital maritime links?

The SA Navy analysed its perceived threat and endeavoured to determine which equipment it would need to be a credible maritime force at the southern tip of Africa. In essence its strategy centred on the security of South African waters by denying any potential enemy freedom of movement in South African waters and protecting the approaches to South African harbours. This had to be guaranteed by creating an effective deterrent and by effective control and surveillance. ${ }^{59}$

A plan followed in which South Africa's naval needs for the last three decades of the twentieth century were expounded. The type of surface combatant the Navy saw as ideal was a vessel big enough to stay at sea in all weather conditions in the often, stormy South African coastal waters. It had to carry enough firepower (including missiles) to deter possible future aggressors, with a maximum speed of at least 30 knots and an endurance of seven days. ${ }^{60}$ A ship therefore of roughly between one and two thousand tons, in other words a typical corvette or light frigate. $^{61}$ The plan regarding South Africa's naval needs for the rest of the twentieth century stipulated (very positively) that the SA Navy's requirements were for a force of 10 frigates or corvettes. ${ }^{62}$

Du Toit, pp 267-8.

MAD. VSH/10/66/10/2. Notule van 'n vergadering gehou the SAV HK te Simonstad op 15 Februarie 1975 om die basiese operasionele buitelyne te bespreek met betrekking tot die ontplooiing van SAV-korvette. Appendix 6: Factors affecting the evaluation of the Maritime Threat to the Republic of South Africa. 1969.

There are a variety of opinions in official documentation regarding the ideal vessel for South African sea conditions. One aspect everybody emphasised is that the ships must have good sea keeping capability and endurance. Some were of the opinion that the ship should be at least $84 \mathrm{~m}$ long and around 1200 ton. However when the Taurus project started most of the staff requirement all indicated a ship of at least some $1800 \mathrm{t}$. Potgieter, Geskiedenis, p 33. 
With the international pressure mounting on South Africa and armaments sales to South Africa being increasingly scrutinised, the local armaments industry underwent tremendous growth and more emphasis was placed on developing the local armament manufacturing capacity. Therefore, as early as February 1969, when the SADF approved the acquisition of six "patrol vessels" the Commandant-General of the SADF (General Hiemstra) already stated that South Africa should build its own "light frigates" in the future. ${ }^{63}$ Because of the international political animosity towards the policies of the South African government, the purchase of military equipment was beginning to become a problem. Already an emphasis was placed on self-sufficiency and consultants were appointed to investigate the local shipbuilding capacity. Later, during the seventies the local armaments industry would undergo tremendous growth.

In order to evaluate the different options regarding new surface combatants for the SA Navy, a project team went to Europe in March 1971. Although they were keen to continue with the SA Naval tradition of acquiring surface warships from Britain, and Edward Heath's Conservative Government were willing to accept orders, the Labour Party indicated that if they would return to office armament orders will be cancelled. Ordering ships from a British yard was therefore too risky. In France the project team were impressed by the French designs, but found them too expensive. As a third alternative and on the insistence of Chief of the Navy, the team visited Portugal to evaluate a 1300-ton corvette. These corvettes (of the Joao Couthinho class equipped with medium speed diesel engines capable of 24 knots) were smaller and slower than the British and French ships with gas turbine engines and a maximum speed of at least 30 knots. ${ }^{64}$ However, they were cheaper and the Minister of Defence, P.W. Botha, preferred the ships to be bought from Portugal, as it would support a politically and economically weak Portugal financially. Portugal and South Africa shared mutual interest in the sub-continent within the Cold War paradigm and as Angola and Mozambique were still Portuguese colonies, South Africa saw Portugal as an ally in Africa. ${ }^{65}$

From the SA Navy's point of view the number of vessels were important and they emphasised that at least six patrol vessels must be acquired. If six vessels were available, at best two out of three vessels could be patrolling the East and West Coasts of South Africa at any one time. Admiral H.H. Biermann (a former Chief of the Navy, then Commandant-General of the SADF) supported the requirement for six vessels, even if it meant less sophisticated vessels. ${ }^{66}$ The choice thus fell on the

AA. Produksievorderingsverslag (Production Report) for the six months ending 30 September 1971, pp 15-16.

MAD. SAWA. VSH10/66/10/2. Aankoop van 6 korvette van Portugal. See also: AA. Memorandum 55/24, 2 December 1971, p 107. Attached to Minutes of Board of Directors of the Armaments Board, nr. 55. 
Portuguese vessels not only because the Navy preferred more, smaller, cheaper and less sophisticated vessels but also for political reasons.

The corvette project (designated Project Taurus) was announced to the press on 10 December 1971, with the arrival of the submarine SAS Emily Hobhouse in Simon's Town. P.W. Botha stated that South Africa was buying six missile corvettes from Portugal and was investigating the possibility of building a number of ships locally. ${ }^{67}$ Reaction was positive, with Afrikaans newspapers reporting that the announcement of the procurement of six "ultra modern corvettes" were loudly welcomed ("onder luide toejuiging"). ${ }^{68}$ At the same time P.W. Botha also referred to the importance of the Cape Sea Route to the "free world" stating that it handled about $20 \%$ of the world's, and $30 \%$ of Europe's oil. ${ }^{69}$

In February 1972 the Taurus project team established its Lisbon office, while a technical team, responsible for weapon systems went to Paris. The Spanish shipyard Bazan was the leading yard and main contractor, while a Portuguese yard, Viana Do Castello, acted as sub-contractor and builder and Thomson CSF were responsible for the weapon systems. However the SA Navy were not interested in the basic Joao Couthinho design, but preferred a bigger more complicated design with upgraded weapon systems. This virtually implied a new design, which meant that the original time scales (to complete the project study phase by October 1972) could not be adhered to. It also made the project more expensive than originally calculated. By September 1973, after a new cost analysis, it became clear that only three instead of six ships could be built. This reflected the inability of the SA Navy and the Armaments Board to design and do proper cost analysis.

During late 1973 the final staff requirements for the vessels were completed and contract negotiations started. A year was given for finalising the contracts, which effectively extended the final completion of the project with another year. $^{70}$ It soon became apparent that Viana Do Castello who had to complete the tender in co-operation with Bazan, would not provide final documents before November 1974. This was attributed to insufficient support from the Portuguese Navy and to the constant changes the SA Navy made in the specifications. Things were constantly being added to the basic design, making the ship bigger and more expensive, while time ran out! ${ }^{71}$

In the meantime P.W. Botha opened negotiations with Israel for the acquisition of six missile strike craft. He informed the President of the Armaments

Volksblad and The Star, 10 December 1971.

Volksblad and Vaderland, 10 December 1971.

Volksblad, 10 December 1971.

AA. K5/19/1/12. Memorandum 75/28, 14 February 1974 and Armaments Board Yearly Report 10, 1973-74, p 20.

AA. Minutes of Board of Directors of the Armaments Board, nr. 78, 8 May 1974, p 11. 
Board of this on 17 April 1974, stressing that since nothing came of the corvette project, a "package deal" must be concluded with Israel. Cabinet was only notified of these developments in June $1974 .^{72}$ This decision was unpopular amongst naval officers, as they believed strike craft was not the solution and that Navy needs bigger patrol vessels as its key surface combatants.

Back in Portugal drastic changes took place. General Antonio de Spinola became the new Portuguese President after a bloodless coup d'etat and the process of granting independence to Portuguese colonies immediately commenced. The Portuguese notified the Armaments Board during June 1974 that they would not continue with the corvette project or act as an intermediary with Spain. For political reasons Spain also did not want to accept the project. ${ }^{73}$ Hereby Taurus was effectively cancelled although the project team had completed the design phase.

Taurus essentially failed because of the long drawn out planning and design phase as well as the bad execution of the project. Initially the vessel was based on the 1300-ton Joao Coutinho class, but as the requirement constantly changed it became a much more sophisticated vessel of 1800 -ton. The SA Navy planners were still suffering from the Royal Navy syndrome, redesigning the ship to make it bigger and more sophisticated - like a Royal Naval vessel. Their lack of experience in designing ships, adhering to tight time scales and managing big integrated projects contributed to the "sinking" of the project.

\section{Concluding remarks}

Because of South Africa's unique location and its easy maritime access to the world, the sea has played an important role in its history. Furthermore its strategic value on the route between Europe and the East were obvious, resulting in competition for control of the Cape. Hence the protection of the settlement at the Cape and the defence of the maritime communications around the southern tip of Africa were very important for the masters of the Cape. For a great part of the South African past, Britain was either responsible for South Africa's maritime defence or had close links with its naval establishment. During and immediately after the Second World War the traditional naval links between South Africa and Britain deepened to such an extent that it became a matter of course. As a result of the Simon's Town Agreement the SA Navy received ships and equipment from Britain and the close ties with the Royal Navy regarding training, exercises, equipment and doctrine ensued for a while.

However during the late fifties, sixties and seventies South Africa's Nationalist Party Government increasingly became ostracised because of its race policies, leading to the growing isolation of South Africa. Considering the close and Minutes of Armaments Board Executive Committee, nr 30, 19 May 1974, p 1. 
links the SA Navy had with Britain this obviously impacted on maritime defence and the status quo changed drastically. Specifically after the cancellation of the Simon's Town Agreement and the severing of the British link, it became imperative for the SA Navy to take the responsibility for its own maritime defence.

In the final analysis, after the "break" with Britain, the SA Navy was on its own. South Africa's internal policies led to the link with Britain being severed, and the efforts to acquire new ships of the type the Navy thought it needed also failed again because of politics. To crown it all, in contrast to the opinion of most of its officers, the "Minister of Defence decided" that the SA Navy must immediately acquire strike craft - not corvettes or frigates. With this the SA Navy truly entered a new era in its history! 